\title{
The relevance of the metaphor of God as Father in a democratic, non-sexist and religious society: An African Christian perspective
}

\author{
Modise, Leepo \\ University of South Africa \\ modislj@unisa.ac.za \\ Wood, Hannelie \\ University of South Africa \\ woodjm@unisa.ac.za
}

\begin{abstract}
This article consists of four parts. Firstly, the article indicates the impact of the ancient contextual factors of using Father as an attribute of God. The position and role of males and females in the ancient times is highlighted to give clear background why the human authors of the Scripture made use of the 'father figure' as the attribute of God. Secondly, attention is given to the revelation of Scripture that God has revealed God-self and how human writers encode the message to suit their context. Thirdly, the question of the relevancy of using God the Father as an attribute of God within a democratic, non-sexist society, and amidst complicated family lives, is addressed. Fourthly, recommendations are made on the multi-faceted attributes of God that can be used interchangeably within the given context. The article argues that God as Spirit is neither male nor female, but incorporeal, and therefore transcends all creation because God is the creator God and cannot be confined to any gender, colour or race.
\end{abstract}

Keywords

Feminism; God; Father; African-Christian; Democratic; non-sexist

\section{Introduction}

\section{The background}

From its emergence as an academic discourse, the proponents of feminist theology have analysed the importance of language in reference to humanity and advocated change from exclusive to inclusive language for 
people. Language for people and the language of God are not separate issues. Thus, the concern rises in this article to find ways of speaking about God that offers alternatives to exclusively male references. This article intends to deconstruct the social construction that God is male. Van WijkBos (1995:5) indicates that change of positions and roles for women within the society will never change the societal structures. She argues that the change of the way of thinking, being and acting with each other is needed. Patriarchy is an ethical system that needs to change from the ground upward.

The question of the relevancy of 'Father' as a metaphor for God is based on the argument of feminist theologians that priority given to males in the Scripture promotes male - domination, exploitation and oppression of women. As God had revealed God-self in Scripture in the masculine, gender has great influence. This influence contributes to the oppression, exploitation and neglected of women in the Church and society.

\section{Aims of the study}

This article attempts to point out the reasons why the human authors of Scripture used the masculine metaphors like Father and Son instead of feminine metaphors like Mother and Daughter of God. In this article the authors will illustrate that it was relevant to refer to God as 'Father' in that time based on the social order and acceptable social constructed truth. In this article, facts will be highlighted to show that 'Father' as metaphor for God is viewed as irrelevant based on the shift of social order, but it has an eschatological purpose to serve as the hope for single parents, orphans and child-headed families. In this article a journey through literature will be taken to search for the possible acceptable genderless metaphor for God or retain the 'Father' metaphor that will create an incomprehensible God to be known to human beings in a democratic, non-sexist and non-racist society.

The research methodology used in this article is inherently a literature study, observations, and document analysis within a semi-rural and rural community in Tswaing municipality. One of the authors is a member, faith leader and faith consultant of this community and was involved in the family support project run by Legae Enrichment Centre, who has been observing the families as well as the behaviour of the fathers within this community. 


\section{The impact of ancient contextual factors on using the metaphor of 'Father' for God}

In ancient times, the rise of patriarchy in the society had a great impact on the use of masculinity in the Holy Scripture, since patriarchy was at the order of the day. The writing and understanding of most documents were done within the patriarchal context. In this sense it is important to trace where patriarchy originated in the society and the entire world.

Patriarchy is a concept for female oppression and has been used over time in a variety of ways. It has been discussed, explained, defined, and contended as an ideology, as a symbolic male principle, as the literal power of the father, as a method of controlling women's sexuality and fertility and as an institutional structure of male domination (Rowbotham 2006:52).

It is contended that 'since the beginning of our story all significant societies were clearly patriarchal with no single exception' (Therborn 2004:17). Patriarchy is explained as a 'system of social structures and practices in which men dominate, oppress and exploit women' (Walby 1990:20) and that Christians of a 'wide range of theological and Biblical positions' generally accept that the culture of the Old Testament is patriarchal (Haas 1995:321). Patriarchy is associated with sexism as being the systematic oppression of women (Scanzoni and Hardesty 1992:1). Patriarchy is androcentric and male-centred where men are the upholders of authority and power whilst women are deprived of any authority or power. In a patriarchal society men are powerful and women are inferior, defective and less human (Van Leeuwen 1993:121, 136-137). Patriarchy 'fosters discrimination and abuses human rights' (Hull 1998:97), and is found in societies wherever it is father-ruled and where it reinforces the subordination of women, as well as the subordination of the weak and marginalised groups to the rich and powerful (Ruether 1983:61).

The origin of social hierarchies, as well as the social and political position that women held throughout the ages, plays a major role in feminist theories. Modern feminists in the 19th century began to question whether or not there was ever a time when women were dominant over men as men dominate women in patriarchal societies. They began to question whether matriarchy could ever have existed (Ehrenberg 1989:63). Some feminists believe that men have dominated and oppressed women throughout 
the ages; this requires that we rely on information from archaeological evidence for the existence or not of patriarchy since the beginning of time. However, two conflicting viewpoints have evolved on whether a matriarchy ever existed before patriarchy, namely the traditionalist and the feminist anthropologist views (Wood 2012).

Traditionalists believe that male domination is universal and natural and, that in religious terms, God created women to be subordinate to men (Lerner 1986:16). The phenomenon of sexual asymmetry, that is the assignment of different tasks and roles to men and women, is the most pervasive reason for the rise of patriarchy, according to traditionalist theorists (Lerner 1986:16). Traditionalist feminists focus on women's reproductive capacity and motherhood as the reasons for the sexual division of labour and see this biological division as functional and just (Lerner 1986:17). Traditionalist views changed over time, especially in their 'defence of male supremacy based on biological-deterministic reasoning' and during the 19th century their views on women's inferiority became 'scientific' (Lerner 1986:18). Darwin's theory of the survival of the fittest became the justification for the unequal distribution of wealth and privileges because of women's biological constitution as 'scientific defenders of patriarchy' (Lerner 1986:18). It was also Freud's theory of the female 'anatomy is destiny' that reinforced traditionalists' explanations of women's subordination and inferiority.

Feminist anthropologists, however, challenged these views. Male domination was not universal, because no evidence has been found of societies in which sexual asymmetry carried any connotation of domination or subordination of women. The sexes were complementary (Lerner 1986:18).

During the mid-twentieth century, the theory of matriarchy became a prominent topic in feminist theory and was fuelled by archaeological digs which pointed to Neolithic iconography that was predominantly female. In the Neolithic era the mother-right was dominant and women received the highest status (Dashu 2005:195). This view could have been the point of the departure for feminists to question and challenge the masculinity of God in the Bible, since the hearers and readers of that time could have not understood the role of this male-God. Heine (1989:74) claims that the topic on the equality of the sexes in pre-history became attractive to the feminists, because they believed that science could provide evidence of the 
historical oppression of women and that the oppression of women was not only biological.

Theorists of matriarchy, although they differ in position, believe that matriarchy existed before the patriarchy. There is archaeological evidence that is inconclusive and problematic, particularly when addressing the issues of women's lives, because the preferred interpretative framework that the individual author and archaeologist present depends on the class of evidence that is expressed (Wood, 2012).

There are many different views on patriarchy and we want to start by sketching some examples of these and how they have been experienced by women. Women's subordination can be traced back to as early as Plato and Aristotle, who both viewed women as inferior, as not being fully human or capable of reasoning, and as generally being weaker in nature than men. In the early Christian tradition, women were depicted as temptresses, as the cause of all sin, as deformed males and as not having been created in the image of God. They were created purely for the purpose of procreation: women had few rights in the public or private spheres of society (Ruether 1985). With the rise of feminism, these views were challenged. In its quest for women's liberation, the feminist movement became a voice and a platform through which women could confront the oppressive nature of patriarchy and through which they could ask life-changing and important questions in order to critique past and present assumptions and paradigms (Wood 2012).

Aristotle and Plato were significant philosophical voices that have influenced Christian thought to a large extent. Although they were not the only non-Christian philosophers, their influence remains significant in the gender debate as both have had a substantial influence on the Church Fathers' views and ideas about women (Wood, 2012).

Traditional Christian dualism originated partly in ancient Greece from the metaphysical theories of Plato and Aristotle. Ruether (1985:65) states:

The influence of... Aristotelian biology on Christian theology... can hardly be underestimated. Aristotle's biology gave 'scientific expression' to the basic patriarchal assumption that the male is the normative and representative expression of the human species and the female is not only secondary and auxiliary to the male but 
lacks full human status in physical strength, moral self-control, and mental capacity. The lesser 'nature' thus confirms the female's subjugation to the male as her 'natural' place in the universe.

Plato (428-347 BC) was the first philosopher to develop a substantial understanding of male and female identity. Plato's views were grounded in his mind-body dualism where the soul or mind was not necessarily reflected in the body, but significantly distant from it (Gonzales 2007:21). Plato's theory on the creation of humankind paved the way for gender inequality. For Plato souls were originally implanted in male bodies and given volition, sensation and emotion (Yen 2003:1).

Plato assigns the creation of women in concurrence with the creation of birds, mammals, reptiles and fish, and had very strong views on the inferiority of women. Since they were not fully human and not capable of reason, their only hope was to return to earth again as men to perfect themselves. For Plato women are those men who have fallen prey to their irrational and emotional features, and therefore as inferior beings, women must be ruled by men (Kasubhai 1996:37, 47).

Tetlow (1980:7) observes that Plato in his Republic stated that women were to be educated only for the good and for the defence of the state, he confines women to their homes and order women to obey men. In his Laws he limited women to traditional sexual roles.

Although Plato was of the opinion that women were capable of performing the same duties as men, he maintained that women are weaker than men and that in order for women to become rulers they were required to divorce themselves from their private and biological role as mothers (Yen 2003:2).

During Aristotle's (384-322 BC) lifetime, both slaves and women were not highly regarded. In his Politics he portrays men as superior to women and, therefore, that males should rule over females. Aristotle alleged that because women did not want to participate in political affairs they were better off being ruled over by men as males. By their very nature, men are more capable of leadership than females. He also maintained the view that men should rule over their wives as they lacked authority, which was critical component of ruling (Kraut 2002:249). Aristotle claimed that 'The courage of a man is shown in commanding of a woman in obeying' (Aristotle in Ruether 2011:65). 
Aristotle also contested that males are superior to females for the reason that they differ physically. Since women are smaller, shorter-lived, weaker and less articulated than men, they should be ruled by men as determined by the natural order of the universe. Whilst men actively provide the soul of children, women only passively provide the matter. He confines 'inferior' women to the household because he argued; matter is less divine than form. Women are not able to exercise public leadership in the Church and society because they are defective beings, lacking mental volition and physical power (Ruether 2011:65).

Aristotle placed women in the same category as slaves and non-Greeks; he alleged that women are naturally servile and created purely for procreation; and that the female status should be looked upon as being reformative (Strachan \& Strachan 1985:2).

Aristotle's texts are indeed perceived to be misogynist, because of his unwavering views that women were inherently inferior to men. Freeland (1994:145-146) states:

Aristotle says that the courage of a man lies in commanding, a woman's lies in obeying; that 'matter yearns for form, as the female for the male and the ugly for the beautiful;' that women have fewer teeth than men; that the female is an incomplete male or 'as it were, a deformity': which contributes only matter and not form to the generation of offspring; that in general 'a woman is perhaps an inferior being': that female characters in a tragedy will be inappropriate if they are too brave or too clever.

Christian teaching has been influenced by Plato and Aristotle. Christian alienation from body and nature stems from the Church fathers and this will be discussed in the next section.

The Latin and Greek Church fathers' writings reflect the times and conditions within which they lived. It finds expression in their dualistic view of the soul and body: God and nature, and male and female. During the period 1-590 AD, Christianity became firmly rooted in the GrecoRoman culture and this period marked a concerted effort to restrict the role of women in the Church. During this period women were allowed to engage in charitable works but were prohibited to undertake religious 
instruction or to administer the sacraments. Women were not considered equal to men (Isherwood and McEwan 2001:57-58).

Not only were the Church fathers' views built upon the anthropology of Aristotle and Plato, but also on Scripture and especially those of Paul. 1 Corinthians 14:34-35 was often cited and used as a justification for gender inequality. They based their views on women from texts such as Genesis 1:27 ; Genesis 2:20-23; Genesis 3:1-24 in the Old Testament and in the New Testament on texts such as 1 Timothy $2: 8-15 ; 1$ Corinthians 11:7-9; 1 Corinthians 14:33-35 ; and Ephesians 5:22-23. Lerner points out that these texts were interpreted in different ways, either literally or allegorically. Literally they pointed to the innate inferiority of women, and allegorically they referred to the human mind whereby the higher intellect belongs to men and the lower intellect to women (Lerner 1993:141).

Human authors were the primary authors of all Scriptures, with the guidance of God through the Holy Spirit. We cannot deny the human participation in bringing forth the Holy Scripture. Human beings received God's revelation through the Holy Spirit and put it in their own words, according to the codes of their times. It stands to reason that the role of the human author in the organic inspiration should be fully recognised. $\mathrm{He}$ wrote from a particular background which differs vastly from the present background. We should therefore consider how his background influenced his thinking and writing. And yet, at the same time, we should never forget that he was, but 'auctor secundarius'. Beyond him there is always the Spirit of God, caring for the inspiration of His or Her Word (Modise 1997:17). So the context of the human authors has influence on the writings of the Holy Scripture.

As is already alluded to, above those human authors of the Holy Scriptures when writing the Word of God, were inspired by the Holy Spirit to do so. But they were also influenced by, or took into consideration the sociocultural background of their time to convey the message of God to the people of their time. Therefore, it is of paramount importance to discuss briefly the socio-cultural background of women living in biblical times. When dealing with the masculine and feminine attributes of God, it is necessary to observe how these attributes fitted into the socio-cultural context of the people to whom God revealed himself to and the ones that would receive that revelation as the final written document. 
Males within the community of Israel held a dominating position. Everything in the family circle - livestock, furniture, servants, children and wives - belonged to the husband and or the father of the household. Within this cultural setting, women are mentioned to be equivalent to properties as is mentioned in Exodus 20:17. Exell and Leale (1985:45) forward three important points concerning the creation of women in Genesis 1:17 and Genesis 2:18-24. In Genesis firstly, states:

Woman was brought to man in order that she might relieve his solitude by intelligent companionship... In order to be true and happy companionship, there must be a fair equality of intellectual power, of the moral sympathy, and a real community of daily life, existing between the parties. Secondly, woman was brought to man that she might be his helpmeet in the struggles of life... Thus woman is man's helpmeet, to rejoice in his joy, to minister to his comfort, and to aid his religious life and worship. Thirdly, woman was brought to man that she might receive his love, protection, and care. Eve was taken from the side of Adam, that she might be equal with him, from near his heart that she might be loved by him, from under his arm that she might be protected by him. Woman was not intended to be man's slave.

Since the male (father or husband) in the Israelite family was the sole person who controlled, provided, protected and governed everybody he was called 'baal' or master, (owner). The proper concept to describe the authority the father held in the family is 'beth ab' 'the house of one's father' (Modise 1997:22).

Thus, from the above argument human authors of the Holy Scriptures used masculine metaphors for God, especially 'Abba' or 'Father' in an analogical sense, taking into consideration the position of human beings in their own cultural situation. They used masculine metaphors for better understanding and for acceptance of God's Word as an authoritative message like the words of the master in the family. Biblical authors perceived God in the same way in the government of God over and God's providence for the whole of God's creation.

Daly serves as a good model of a radical feminist for whom the core symbol of the Christian tradition of God as Father, and the maleness of God and 
Christ legitimate and reinforce male power in society - something she believed women could not identify with. Daly (1968) argued that patriarchy, with its misogynistic agenda, works through theology, metaphysics and language in order to victimise women in every sphere of their lives. Women throughout the ages had only role models fashioned by patriarchal males (Wood, 2012). Daly challenged the masculinity of God derived from the argument that male domination, oppression, and exploitation of males in the family is influenced or encouraged by the masculinity of God in Scripture, and called for the deconstruction of the masculinity of God in the Scripture. In the present situation within a democratic, non-sexist and multi-religious country, there is a paradigm shift within the social order where there is no more stable families, where fathers are perceived as protector, provider and family lover. The previous statement will be justified in the following section, about 'The relevancy of the utilization of the metaphor of father for God in Scripture,' where statistics will be provided. In South Africa many men are acting like beasts towards women and children. These men do not love, protect and care for their families. There are continuous reports of rape, brutal murders and serial killings by men. In the rest of this article, the researchers will attempt to indicate that metaphors based on human beings for God are relevant when the behaviour of human beings is corresponding with the attributes of God. The next section will examine the relevancy of God as the father as compared to the behaviour of males, or the family setting in the contemporary society.

\section{The relevance of the utilization of the metaphor of 'Father' for God in the modern context}

It is indicated in the above paragraphs that human writers of the Scripture have used their own culture, tradition and experience to encode the message of God in Scripture. When the researchers based their attention towards what is said above, there is a clear indication that God was called the father because of the tradition and culture in which the people were living. Human writers did not have words to express God's activities as they saw them, in this fact, human writers used the metaphors father to express God's attributes and acts of protection, providence and caring for society and the family. This is the reason why they referred to God as 'Father.' 
The question that we need to respond to is: 'Is the metaphor 'Father' in the modern context justifiable to refer to God in the world we live in?' For us to respond to this question we need to relate the modern society to the ancient times, when God was described by human authors in terms of their sociocultural context. In that context God was referred to as protector, provider and care-giver, which was the task of the father in the family. In this article we need to compare these two situations and deduce whether $s$ it is still relevant to refer to God as 'Father' in the contemporary society.

There are several indicators in the contemporary society which demonstrate the deterioration of families and social life locally and the global level. However, the authors of this article have decided to rather focus on a small community near Sannieshof in the North-West Province of South Africa, called Agisanang. This community is described in terms of a multiverse of life-worlds fused into first, second, third, fourth, fifth, and sixth worlds. These worlds are easily recognisable using different terms and phraseology for different societal communities categorised into visible spatial compounds and contextual spheres (Modise 2011:66).

Modise (2011:66) categories these mixed societies in South Africa as follows:

- upper class suburbs and city centres of Sandton, Johannesburg, Cape Town, etcetera as first world,

- some city suburbs, villages, towns or middle class township areas as second world,

- some city-like suburbs, townships, locations of semi-urban and semirural areas of the middle class, working class and unemployed as third world,

- rural settings and settlement areas of so-called traditionally inclined people, the working class and the unemployed as fourth world,

- pockets of unorganised city and village and rural settlement areas as 'underclass' and poverty stricken areas as fifth world and

- temporary established squatter and settlement areas next to busy roads as rapidly changing squatter and settlement situational settings as sixth world. 
The semi-rural and semi-urban areas of Agisanang near Sannieshof constitute a mixed category of city-like suburbs, townships, locations and settings in which rural people as part of the fourth world category of Modise has become urbanized in many respects. One of the functions of the semi-rural and semi-urban areas is to cater for rural people in one sense, but these semi-rural and semi-urban areas also catered for some of the needs of people from third, second and first world settlements and areas. Again the researchers' guesstimate is that features from nearly all six worlds described above are to be found in semi-rural and semiurban settings and communities where people are directly or indirectly involved through their professional activities. In this article the researchers define Agisanang as a semi-rural setting and area, as one in which the inhabitants are in many instances being urbanized, one of which is the rural integrated plan of the South African local Government Demarcation Act. The Agisanang investigative Centre is located within the area where poverty and unemployment can be experienced by its inhabitants. Due to unemployment and poverty, which is a social fact in thus this community, families are deteriorating because males and females are visiting other areas to look for work.

There are indications in Agisanang that the community's moral and spiritual decline, is due to the increased number of young people being reared by their mothers without the benefit of a father. The reason for this decline is migrant labour or irresponsible fathers that could not take the responsibility for their children. Even when the father is present, he is often fully preoccupied with a demanding job and his career. His influence over a family's daily affairs often would not even be noticed except for the pay check he provides. The generic modern father is often remote, indifferent, unapproachable, and unavailable. $\mathrm{He}$ is a member of a misunderstood endangered species known as 'father.'

The reference to God as 'Father' and the use of this metaphor (Father), as has been said, means that the Fatherhood of God cannot be measured against the fatherhood of man. The fatherhood of man does not constitute the Fatherhood of God within the community. In the democratic, nonsexist and multi-religious society where single-parenting occur more than father headed families God the father is the only hope for these families. 
The omnipresence of God as the 'Father' cannot be realised as, there is a very limited father figure in this community.

The South African Statistics show that there are 48, 7\% of males, while there are 51, $3 \%$ female within the total population of South Africa. These Statistics indicate that females are in the majority in South Africa. According to the statistics of the investigative centre named Agisanang there is $47,95 \%$ of males, while females are $52,05 \%$ of the total population of the community (Stats SA, 2011). There are only 33\% of children living with both parents in South Africa. Just over $39 \%$ of children live with their mothers. About $4 \%$ of children live with their fathers only. $8 \%$ of children live with their social grant parents, grand aunts or uncles, but without their own parents. $0,5 \%$ of children live in child-headed households. The $16 \%$ of children included those living in care homes and relatives other than their biological parents.

The statistics above describe the family situation in South Africa. The family is no longer a stable structure where the father can be placed in the centre of the family as the pillar of the family to provide, protect and take care of the family. In the present situation there is an absence of the father, particularly in the family, but also in the community in general.

In societies where the role of the father seems to be irrelevant, detached and impersonal, the archetype of the 'great mother' seems often to be followed. This means that young people grow up careless and there may be tendency to be slow to take on responsible adult roles in society. Based on one of the authors' observation, when the religion of the 'great mother' prevails, moral standards drift into permissiveness, narcissism, and self-indulgence, because righteous authority and accountability tend to be lacking. Some of the excesses of the women's rights and liberation movements can be attributed in part to the global absence of the father. It is well known that children, for instance, who have been sexually abused by a father grow up to become abusers themselves in many cases. 


\section{Description of the Investigative Centre and the research method employed to collect data}

The researchers have chosen the Legae Enrichment Centre in Agisanang as the investigative centre, for the reason that it is a family support centre. This centre was established in 2006 by Mr K Seabo and one of the authors of this article, Prof Leepo Modise, had addressed the family problems that were accounted by the residents of Agisanang. It is a Non-Profit Organisation (NPO), registered as such and funded by the Department of Social Development in the North West Province. They are utilising the services of a local social worker for counselling and other professional services. Besides family support, the centre provides the following services:

- Workshops on parenting skills.

- Workshops on marriage enrichment.

- Workshops on pre-marriage preparation.

- Workshops on substances abuse.

- Assisting single-parent and orphans to apply for social grants.

- Doing counselling for children and parents.

- Doing educational motivation and career guidance (Legae Enrichment Centre brochure, 2012).

This centre is used by the community of Sannieshof and the neighbouring farmers and towns like Ottosdal and Delerayville. People with family problems consult Legae caregivers for assistance and support. Children with social or educational problems consult Legae caregivers for assistance and support.

The authors used the qualitative research method to collect data from Legae Enrichment Centre, where observation and document analysis were used. As is stated, one of the authors is the founder member of the Legae Enrichment Centre and he worked as a volunteer for more than ten years in this organization. He has observed people visiting the organisation for help and support. Using these observations, with the consent of the organisation and people who consulted the organisation, the authors has collected the data being utilised in this article. The following documents were consulted and analysed: 
- The attendance register which gives the date, name and purpose of the visit.

- Volunteers' weekly report forms, from house visitation.

- The Organisation's monthly reports to the Department of Social development.

- Referral letters to the local social worker.

The authors have find that there are clients who visited the organisation for family support and other social ills issues. In the next section the authors will discuss the findings using Legae Enrichment Centre as investigative centre.

\section{The finding from observation and document analysis at Legae Enrichment Centre}

In this article the authors have been discussing above, the utilisation of the metaphor of the 'Father' for God and how the context played a major role in bringing the message of God. Literature review and statistics have illustrated the absence of the father in society. The Legae Enrichment Centre was used to verify the literature and statistical findings.

The research method, namely a literature study; observation and document analysis employed in this article has led authors to the following findings on conditions and situations in the community:

- Single parents, looking for application forms for child grants

- Child headed households consulting the centre for assistance for application for orphans' grant.

- Abused Women and domestic violence,

- Lack of financial and moral support of fathers who are working in cities;

- Substance abuse by youth due to lack of a stable family. 


\section{Recommendations}

The following recommendations are presented:

\section{The radical stance}

- The radical stance for changing of the patriarchal metaphor to a feminist metaphor, is not practically possible due to tradition and culture. Instead transculturalism ${ }^{1}$ is recommended for people to live in harmony within a patriarchal society with feminist challenges.

\section{The moderate stance}

- The metaphors to be used for God should be more neutral than patriarchal or matriarchal in nature. God the 'Father' should be seen as a hope for fatherless children in society. Hence the Belhar confession states that, God in a special way is the God of the poor, orphans, widows, destitute (child-headed family and single parents) and the wronged. In this instead God stands on the side of dependent and vulnerable people (Belhar confession, 1986: Article 4). It is therefore recommended that the fatherless family should see God in that sense, of being God of the fatherless.

\section{Theological stance}

- God is transcendent, he is beyond the culture, tradition, race and gender. God as Spirit is neither male nor female, but incorporeal, and transcends all creation because is the creator God and cannot be confined to any gender, colour or race.

\section{Conclusion}

In conclusion, there is a clear indication from the literature study that patriarchy was the family and societal system at almost all times. Even the writers of the Holy Scriptures utilized the sexist language to express the being of God. During the reconstruction of the society, roles, positions

1 Epstein (1999:24-25) indicates that, the concept 'transculture' as a different model of cultural development. Furthermore, he defines 'transculture' as, an open system of symbolic alternatives to existing cultures and their established sign systems and a way of expanding the limits of our ethnic, professional, linguistic, and other identities to new levels if indeterminacy and virtuality. 
and responsibilities have changed from a father figure with responsibility, to different family structures, like single parents, child-headed family and less father headed families. For feminist theologians and academics it could have been irrelevant to use the metaphor of father for God, but for the fatherless children God as the Father stands as the last hope for them. These fatherless children or single female parents see this God as the provider, protector and sustainer. In this sense the use of the metaphor father is very relevant to the fatherless family.

\section{Work consulted}

Belhar Confession, 1986. Cape Town: CLF publishers.

Berkhof, L 1933. Manual of Christian Doctrine. Grand Rapids: WMB Eerdmans Printing Co.

Clark, EA 1994. Ideology, History, and the Constuction of 'Woman' in late Ancient Christianity. Journal of Early Christian Studies 2 (2): pp. 155184.

Collins, AY 1985. Feminist perspectives on Biblical scholarship. Georgia Atlanta

Cone, JM 1975. God of the Oppressed. New York: The Seabury Press

Daly, M 1968. The Church and the Second Sex. New York: Harper and Row.

Dashu, M 2005. Knocking down Straw Dolls: A Critique of Cynthia Eller's The Myth of Matriarchal Prehistory. Feminist Theology 200513 (2): pp. 185-216

Epstein, MN 1999. From Culturology to Transculture. In Transcultural Experiments: Russian and American Models of creative communication, ed. E. E. Berry and M.N Epstein. New York: St. Martin's Press.

Esler, PF 2005. New Testament Theology: Communion and Community, London: Society for Promoting Christian knowledge 
Ehrenberg, M 1989. Women in Prehistory. London: British Museum Publications Ltd.

Exell, JS and Leale, TH 1985. Preacher's Homiletical commentary on the Book of Genesis. London.

Freeland, C 1994. Nourishing Seculation: A Feminist Reading of Aristotelian Science. In Bar On, B. (ed.) Engendering Origins: Critical Feminist Readings in Plato and Aristotle. Albany: State University of New York Press (pp 145-146).

Gonzales, MA 2007. Created in God's Image. An Introduction to Feminist Theological Anthrolopogy. New York: Orbis Books.

Groothuis, RM 1997. Good News for the Women. A Biblical Picture of Gender Equality. Grand Rapids: Baker Books.

Haas, G 1995. Patriarchy as an Evil that God Tolerated: Analysis and Implications for the Authority of Scripture. Journal of Evangelical Theological Society, 38 (3): pp. 321-336.

Heine, S 1989. Matriarchs, Goddesses, and Images of God. A Critique of a Feminist Theology. Translated from German by J. Bowden. Minneapolis: Augsburg Fortress.

Hull, GG 1987. Equal to Serve: Women and Men in the Church and Home (Crucial Questions Book). Grand Rapids: Fleming H Revell Co.

Isherwood, L \& McEwan, D 2001. Introducing Feminist Theology. Sheffield: Sheffield Academic Press.

Kasubhai, MK 1996. Destabilizing Power in Rape: Why consent Theory in Rape Law is Turned on its Head. Wisconsin Women's Law Journal, 11: pp37-47.

Kraut, R 2002. Aristotle: Political Philosophy. New York: Oxford University Press.

Larkin, WJ 1988. Culture and Biblical hermeneutics. New York: Baker House Company.

Lerner, G 1986. The Creation of Patriarchy. New York: Oxford University Press. 
Modise, LJ 1997. Feminist Theology and Masculine aspects of God's Selfrevelation in Scripture (BD Thesis). Pietersburg: University of the North.

Modise, L 2011. Reflections on the wellbeing levels of professionals In rural areas: A faith theoretical perspective. Saarbrucken, German: Lambert Publishing GmbH \& Co.KG.

Ranke-Heinemann, U 1990. Eunuchs for the Kingdom of Heaven. London: André Deutsch.

Roberts, JD 1993. Black Theology. A documentary history. Volume one: 1966-1979. Cone, J.M And Wilmore, GS (Eds). New York: Maryknoll.

Rowbotham, S 2006. The Trouble with 'Patriarchy. In Morgan S. (ed.) The Feminist History Reader. London: Routledge.

Ruether, RR 1983. Sexism and God-Talk: Toward a Feminist Theology. Boston: Beacon Press.

Ruether, RR 1985. Woman guides: Readings Towards a Feminist Theology. Boston: Beacon Press.

Ruether, RR 2011. Should Women Want Women Priests or WomenChurch? Feminist Theology, 20 (1): pp. 63-72.

Sawyer, DF 1996. Women and Religion in the First Christian Centuries. London: Routledge.

Scanzoni, LD \& Hardesty, NA 1992. All We're Meant to Be: Biblical Feminism for Today. Grand Rapids: Eerdmans.

Statistics South Africa (Stats SA). Social profile of vulnerable groups in South Africa

2002-2011. Pretoria: Statistics South Africa, 2012a.

Statistics South Africa (Stats SA). GHS Series, volume IV, Food security and

Agriculture, 2002-2011: In-depth analysis of the General Household Survey data. Pretoria: Statistics South Africa, 2012b. 
Strachan E \& Strachan G 1985. The devil's gateway. Dunbar: Labarum Publications

Therborn, G 2004. Between sex and power - Family in the world, 19002000. London: Routledge.

Tetlow, EM 1980. The status of Women in the Greek, Roman and Jewish Society. Women in Ministry in the New Testament. New York: Paulist Press.

Van Leeuwen, MS 1993. After Eden: Facing the Challenge of Gender Reconciliation. Grand Rapids: Paternoster.

Van-Wijk Bos, JW 1995. Reimaging God: The Case for Scriptural Diversity. Louisville: Westminster: John Knox Press.

Vogt, K 2003. Becoming Male: One aspect of an Early Christian Anthropology. In. Soskice J.M. \& Lipton D. (eds.) Feminism and Theology: Oxford Readings in Feminism. Oxford: University Press, pp. 49-61.

Walby, S 1990. Theorizing patriarchy. Oxford: Blackwell.

Wood, MJ 2012. Patriarchy, Feminism, and Mary Daly: A systematicTheological enquiry into Daly's engagement with Gender issues in Christian Theology. (Dth Thesis). Pretoria: Unisa.

Yen, RJ 2003. Gender in Judeo-Christian Tradition: A Critique on Christian Feminist Philosophies and a Presentation of the Loyalist View. Quodlibet Journal 5 (2-3) [online] Available at http://www.quodlibet. net/articles/yen-gender.shtml. Accessed 4 November 2010. 